\title{
STUDY OF DECORATIVE VARIETY IN GORONTALO KARAWO FABRIC IN AESTHETIC AND SYMBOLIC ELEMENTS
}

\author{
Apsari Dj. Hasan \\ Postgraduate Faculty Design Master's Study Program \\ Universitas Komputer Indonesia \\ Jl. Dago (Ir. H. Djuanda) 160-162, Bandung, 40132 \\ e-mail: apsarihasan18@gmail.com \\ Reviewer: n/a \\ Accepted: n/a \\ Published: 2019-03-15
}

Received: $\mathrm{n} / \mathrm{a} \quad$ Revised: $\mathrm{n} / \mathrm{a}$

Editor: Abay D Subarna

\begin{abstract}
This study aims to examine the decorative types of Gorontalo Karawo fabrics in aesthetic and symbolic elements. Researchers want to know as made in the research design, aspects that are present in the decoration of fabrics in aesthetic and symbolic elements. This study uses a number of related theories to get results, and as a determinant, the authors use aesthetic theory, as well as historical approaches. With this theoretical basis, the author seeks to describe the aesthetic aspects and symbolic meanings that exist in Gorontalo Karawo fabric. Through the data collection of the chosen motif and provide a classification of motives, the part is used as a reference for research material.

The results showed that Gorontalo filigree had an aesthetic value consisting of unity formed from the overall decorative motifs displayed, complexity formed by complexity in the manufacturing process, and intensity of seriousness in the manufacturing process or the impression displayed on the filigree motif. The aesthetic form also reflects the diversity of meanings for communication, such as the symbol of a leader with his noble instincts, a symbol of cultural cooperation, which is worth maintaining, and ideas about nature conservation. This research proves that the decoration in Gorontalo filigree cloth (Karawo) does not only act as a visual value, but also as a communication of cultural meanings and social status. Of all these distinctive motifs show a relationship between humans and humans and humans with nature. The influence of culture from the Philippines is also known to have a strong influence on the emergence of the Gorontalo filigree namely manila filigree.
\end{abstract}

Keywords: ornamental, aesthetic, filigree Gorontalo (Karawo)

Abstrak. Penelitian ini bertujuan untuk menguji jenis-jenis dekoratif kain Karawo Gorontalo
dalam unsur estetika dan simbolik. Peneliti ingin tahu seperti yang dibuat dalam desain penelitian,
aspek yang hadir dalam dekorasi kain dalam elemen estetika dan simbolik. Penelitian ini
menggunakan sejumlah teori terkait untuk mendapatkan hasil, dan sebagai penentu, penulis
menggunakan teori estetika, serta pendekatan historis. Dengan dasar teori ini, penulis berupaya
untuk menggambarkan aspek estetika dan makna simbolik yang ada pada kain Karawo Gorontalo.
Melalui pengumpulan data motif yang dipilih dan memberikan klasifikasi motif, bagian tersebut
digunakan sebagai referensi untuk bahan penelitian.
Hasil penelitian menunjukkan bahwa kerawang Gorontalo memiliki nilai estetika yang terdiri dari
kesatuan yang terbentuk dari keseluruhan motif dekoratif yang ditampilkan, kompleksitas yang
dibentuk oleh kompleksitas dalam proses pembuatan, dan intensitas keseriusan dalam proses
pembuatan atau kesan yang ditampilkan pada motif kerawang. Bentuk estetika juga
mencerminkan keberagaman makna untuk komunikasi, seperti lambang seorang pemimpin

Publisher: Universitas Komputer Indonesia

Copyright: The Author(s) 2018 DOI: 10.34010/artic.2019.3.2506.121-134 
dengan naluri mulianya, simbol kerja sama budaya, yang pantas dipertahankan, dan gagasan tentang pelestarian alam. Penelitian ini membuktikan bahwa hiasan pada kain kerawang Gorontalo (Karawo) tidak hanya bertindak sebagai nilai visual, tetapi juga sebagai komunikasi makna budaya dan status sosial. Dari semua motif khas ini menunjukkan hubungan antara manusia dengan manusia dan manusia dengan alam. Pengaruh budaya dari Filipina juga diketahui memiliki pengaruh yang kuat terhadap kemunculan kerawang Gorontalo yaitu kerawang manila.

Kata kunci: Estetika; Kerawang Gorontalo (Karawo);Ornamen.

\section{INTRODUCTION}

Indonesian encyclopedias interpret filigree as a technique in weaving or embroidery by pulling, cutting or binding threads so that certain patterns are formed. Filigree techniques are applied to various crafts by forming hole patterns so as to allow light to enter [1].

Filigree craft can be interpreted as a type of art that produces various items of furniture, ornaments or other artistic items made of various media, formed through fabric hole patterns that allow light to enter.

Based on the statement above, Gorontalo filigree handicrafts which in Gorontalo language are called Karawo can be concluded as a type of artistic work made of fine holes fabric, embroidered or dotted by pulling, cutting or binding thread so that certain patterns are formed. The manufacturing process uses a simple tool using hand speed to produce a variety of household products that have useful value for everyday human needs.

Currently embroidery need to be a superior commodity in Gorontalo Province, so various embroidery programs for Karawo crafts that have now obtained patent rights from the Indonesian Government are increasingly empowered for economic development while preserving and preserving Gorontalo's cultural heritage.

Filigree craft is a work that keeps the history of the development of the social life of Gorontalo people that has been built by ancestors as a reflected cultural heritage in every filigree handicraft product where the meaning contained in the Karawo motif is increasingly ignored by its inhabitants.

This phenomenon becomes very interesting to study, study, and describe as a document in the form of writing so that the description can be read and understood by Gorontalo people in particular and the outside community of Gorontalo in general related to the meanings, forms and techniques contained in Karawo crafts.

The research focuses on aspects that are present in Gorontalo Karawo fabric decoration in aesthetic and symbolic elements.

\section{METHOD}

This research in general is research in the field of design that addresses filigree as an object of study, and designs of Gorontalo filigree fabric as a case study. This research will produce a description of deep understanding of filigree, especially based on the culture of Gorontalo society. So that the research method used is descriptive qualitative.

A qualitative approach is an approach that focuses attention with various methods, including interpretive and naturalistic approaches to the subject of study [2].

In collecting data, researchers conducted several approaches, among others:

1. Literature Study

First, a literature study was conducted on the object of research, namely Gorontalo filigree. Researchers refer to research. The next approach used is the study of literature on relevant theories in this study. Several articles from print media sources (newspapers and magazines) and related internet are also studied as references.

2. Observations 
Observation were made to obtain data on the form of Karawo artwork, in discussing the chronological problems of the development of Karawo art and the forms of Karawo artwork. Data about forms include: motives, materials, techniques and other visual elements. Form data also relates to the appearance or function of Karawo art. The data is obtained from the source namely Karawo artworks. The observation step begins with the determination of samples of Karawo artworks based on the types of motives. In observation, supporting equipment such as computers and cameras are used as tools to record objects.

3. Interviews

In-depth interviews or interviews as an effort to collect data are also carried out with parties involved in the object and problem. Interviews with informants were conducted to obtain linguistic (verbal) data, using in-depth interview techniques, namely flexible and open interviews to obtain honest and authentic information related to informants' experiences, attitudes, feelings and views on Karawo art. This interview technique is carried out on all informants, namely: creators, namely designers and craftsmen experts (experts), observers or art observers and Karawo art researchers and cultural experts.

\section{RESULTS AND DISCUSSION}

\subsection{Overview of Karawo Gorontalo Fabrics}

Karawo is a technique for forming ornaments in textiles through the process of designing, cutting, and retracting certain parts of textile fibers to create a base field, then re-embroidering the fibers drawn out to produce certain parts of textile fibers to create a base field, then re-embroidering the fibers drawn out to produce various motives.

For Malay people, embroidery has been known for centuries. Sulam is a symbol of women's personality policies. Embroideries are so inherent in the life and socio-culture of the Nusantara people [3].

Structural motifs formed using the Karawo technique in textiles are called ornamental textiles, or known as "Karawo ornaments", and textiles decorated with Karawo ornaments are called "Karawo textiles". Production and ornamental products emerged and developed massively in Gorontalo Province, Indonesia. Karawo textile production is carried out by Gorontalo women from generation to generation, so this practice is considered a symbol of women's subordination in Gorontalo Province.

Making Karawo ornaments does not only rely on hand skills, but also involves various expressions of feeling, to produce unique and aesthetic ornaments, which are rich in symbolic value. Therefore, Karawo ornaments are considered as a symbol of the creativity and expression of the beauty of Gorontalo people [4].

This shows that the production and product of Karawo ornaments have taken root in the social and cultural life of the people of Gorontalo. The uniqueness and beauty of the form of Karawo ornaments, which reflect many values for communication, have not been fully revealed, and thus, their existence has little contribution to the development of art.

\subsection{History of Karawo Gorontalo Cloth}

The tradition of moKarawo or making embroidery is a piece of history that has been saved by Gorontalo women. Since when Karawo was in Gorontalo and who introduced it, it is no longer known. The data obtained both verbally and in writing about the origin of Karawo in Gorontalo is very diverse. There are opinions that say that Karawo was known in Gorontalo since the Dutch era which was around 1838, some said Karawo was known by the people of Gorontalo in 1917 that even other sources said that Karawo was known by the Gorontalo community since 1713. From various data it can be estimated that Karawo was known by the people of Gorontalo since 
the 18th century during the Dutch colonial period. In the past the Dutch tried to eliminate various local traditions and identities.

The tools and materials used for embroidery in the 18th century are still very simple. Gorontalo women use bamboo as a knife or they are called pseudo which is used as a tool to cut cloth and thread, sticks and bamboo are drawn to resemble needles used for embroidering, used fabrics are used fabrics or called balacu (thin cloth similar to flour sacks) while the yarn used comes from pineapple leaves which are inscribed (fiber taken) then dried, then begins to develop they use kapok which is spun itself and then made into yarn, and sleeping pillows are used as serving to stretch the fabric to be embroidered. For color, they only use the original colors from the fibers of the leaves of pineapple and cotton which are spun themselves.

Starting from the cross stitch of handicrafts made by Dutch women. Seeing the cross stitch, the women in Huntu Village were interested and tried to make things similar to Dutch women's crafts. With simple materials and equipment they start trying to make leto (lenso or handkerchief). That is the embryo of Karawo's existence which is now known and spread throughout the Gorontalo region.

In 1959 traders from the Philippines entered the North Sulawesi area to Gorontalo. They carry a cloth in the form of a cross stitch that uses colorful threads. The beauty of the fabric stole the attention of Gorontalo women who finally gave birth to the idea of Gorontalo women to make a similar decoration called Karawo Manila as it is well known today.

Unlike Karawo Ikat, Karawo Manila uses colorful threads to produce a more beautiful design. Like its name, Karawo Manila is taken from the name of the Philippine capital, Manila, because of the influence of cloth brought by traders and women from the Philippines (Figure 1).

Karawo in Indonesian is called kerawang, has the following meaning: The word Karawo is called Kalawo. Old people have had difficulty in calling the consonant " $r$ " so Karawo is called Kalawo. The word Kalawo stands for Ka = kakayita (interlocking), La = lalantiya / rarandeg (mutual chain) and Wo = wowoala (separated from each other). This means that embroidering work is done by linking one thread to another thread and chain. If it is wrong to do it, then the threads that have interconnected and chain each other cannot be separated or reopened [5].

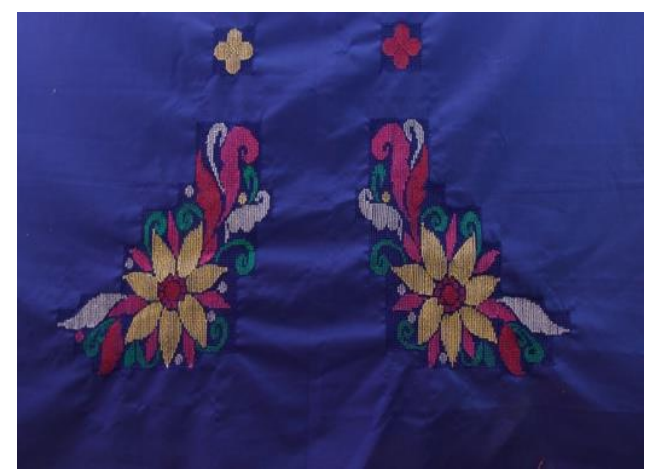

Figure 1. Karawo Manila

Source: Personal photo, January 2019

\subsection{Aesthetic and Symbolic Studies of Ornamental Variety (Motif) in Karawo Gorontalo Fabrics}

The aesthetic form study aims to reveal the aesthetic concepts of Karawo art, so that the study is focused on the aesthetic aspects of Karawo artworks, with analysis of interpretation and analysis of interactions.

Artwork as an aesthetic object contains three fundamental aspects, namely: 1) appearance, consisting of form or structure; 2) weight or content as the meaning of the form consists of: mood, ideas, and likeness or message; 3) appearance (presentation) includes: talent, skills, facilities or 
media (medium). The Karawo artworks as an aesthetic object basically also contain these three aspects, although the elements contained in these three aspects are not exactly the same as other works of art [6].

In ornament art, the basic elements consist of motifs that can be points, lines, fields, spaces along with colors and textures, with certain patterns. Patterns are compositions that are designed from one or more motives that are repetitioned and arranged in a regular order with the principles of arrangement, arrangement and balance [7].

The weight (content or meaning) of the art revealed by the observer is the result of the response or interpretation of the quality of the form of work created by the artist or creator, so the physical form of the work belongs to the artist or creator or content belongs to the observer [8].

\subsubsection{Decoration Position}

In clothing, the position of Karawo artwork is usually placed in the center of the view, for example, in the pocket of a shirt or koko shirt for men, in the wrist of the shirt, on the front of the body on women's dresses or clothing and at the bottom of the skirt. This type of decoration usually consists of a large main motif and a smaller supporting motif. Whereas in other products such as bags, wallets, fans, ornaments for cup placards, tablecloths, glass covers, the position of the motif is placed in the middle of the object or decoration. The purpose of laying the decoration is; so that it can be easily seen and recognized.

\subsubsection{Color}

Talking about the color issue, it cannot be separated from the development of the mindset and artistic inspiration of Gorontalo people which is applied to the decoration of Gorontalo filigree fabric.

Understandably, at the beginning the coloring agent as the main ingredient in giving motifs to Gorontalo filigree cloths made use of natural materials such as mangrove bark, turmeric and Moringa leaves. So the decorative colors that have been finished are the same as the color of the material used, which is natural color.

Traditional dyes which were originally used came from plants with very simple processing. In the current development, the colors in the ornamental motifs of Gorontalo filigree fabric have used various types.

In Gorontalo customs, each color has a specific meaning or symbol. Therefore, in the traditional ceremony the Gorontalo people only use four main colors, namely red in Gorontalo language meelamo, green in Gorontalo Moidu language, golden yellow, and purple in Gorontalo Tilabataila. Likewise in the use of colors in Gorontalo filigree cloth. At the beginning of its development, Karawo only used these four colors.

The red color in Gorontalo indigenous peoples means courage and responsibility, green means fertility, prosperity, peace, piety, sincerity and harmony, golden yellow means glory, loyalty, greatness, and honesty while the purple color means 'grace and authority'.

In general, Gorontalo indigenous people are reluctant to wear brown clothes because chocolate symbolizes 'land'. Therefore, if they want to wear dark clothes, then they will choose black in Gorontalo language moyitomo which means 'firmness and piety towards the One and Only God'. White color means 'chastity or grief'. Therefore, Gorontalo people prefer to wear white if they go to a place of mourning or grief or to a place of worship (mosque). Light blue is often worn at the time of 40 days of grief, while dark blue is worn on the 100th day of grief.

As the development of the use of colors in Gorontalo filigree cloths is increasingly being developed, from the beginning only using red, green, golden yellow, and purple now Gorontalo filigree has used modern colors such as orange, silver and pink.

\subsubsection{Decoration Making Techniques}


The decorative items found in Gorontalo filigree are generally made with embroidery techniques. Craftsmen wrap thread lines with one turn. This is intended to strengthen the thread lines that are not embroidered so that the final embroidery results look sturdy and strong.

The stages of making the embroidery process are basically only divided into three stages, namely iris and pulling thread, embroidering and finishing. In the process of iris and pulling the thread is how to form a boundary and plan the area of the field to be filled with Karawo based on the existing image pattern. The sharpness and accuracy of counting the threads that will be sliced and removed, will determine the yield and smoothness of the workmanship in Karawo embroidery. With a neat and orderly extraction and slicing area, you will get neat and smooth embroidery.

The tool used to slice and pull out the yarn fibers usually uses a number 6 sewing needle and razor blade as a slicer. The needles are infiltrated below and above the fabric construction thread as long as planned. The thread to be sliced is located on top of the needle and vice versa the remaining thread is under the needle. After the boundaries of the field to be formed are finished sliced, then the sliced yarn is immediately pulled out and in the form of a Kerangangan or translucent construction in the plane of the slice to be embroidered (Figure 2). Benchmarks in the slicing process and extraction of yarn fibers are determined by the type of fabric to be embroidered. After it is finished, then the next design begins to apply the motif to the cloth that has been removed

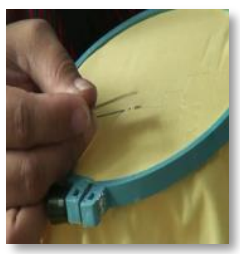

1

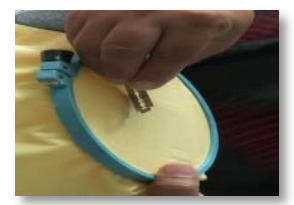

2

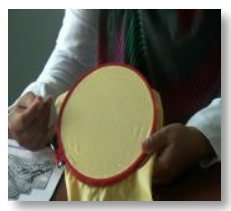

3

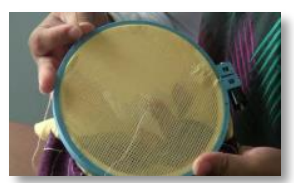

4

Figure 2. Stage of slicing and pulling thread until a raw field is formed on the fabric Source: personal photo, January 2019

After determining the position or location of the raw field to be sliced, the cloth is spread out on the table so that the threads of the fabric of the fabric appear clearer. There are times when the yarn to be sliced is marked with a pencil according to the size that will be made in the raw field. This is usually done by a beginner slicer to avoid slicing, or by an old slicer to help see the fabric fibers to be sliced.

What is interesting in working on Karawo techniques is done manually without the help of a machine. In addition, the workmanship of different threads, pull out threads, and tie Karawo. Therefore, the quality of each stage of production needs to be maintained.

The process of forming a motif with a embroidery technique between Gorontalo Karawo art and the embroidery of Bukittinggi overlay is also different. In Gorontalo Karawo art, motifs are formed before yarns that are uprooted in the raw field are tied and in the sum, whereas in Bukittinggi overlay embroidery, new motifs are formed after the threads are pulled out in the overlay field (Figure $\underline{3}, \underline{4}$, and $\underline{5}$ ) [9].

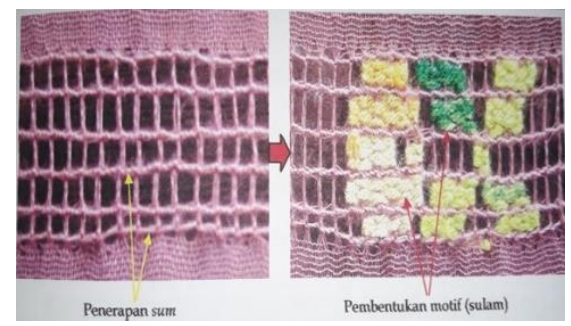

Figure 3. Establishment of the Bukittinggi overlay motif Source: Sudana 2017 


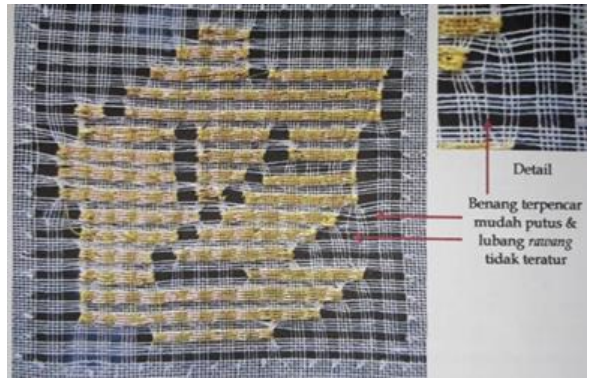

Figure 4. Formation of Gorontalo openwork embroidery motif after application of sum Source: Sudana 2017

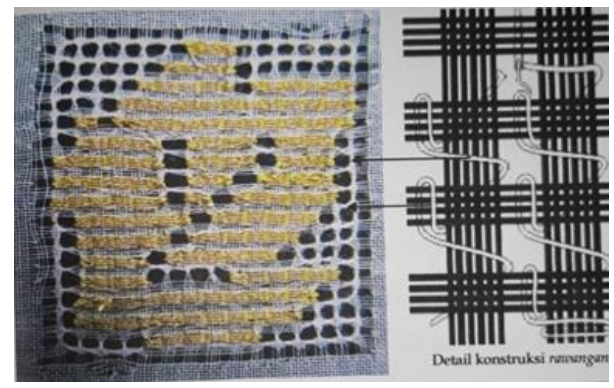

Figure 5. Establishment of Gorontalo filigree motif before application of sum Source: Sudana 2017

\subsubsection{Analysis of Symbolic Meanings of Ornamental Variety (Motif) of Gorontalo Openwork Cloth (Karawo)}

In the study of the meanings of ornamentation available in Gorontalo filigree, the basic triangle is used: linkages between Gorontalo filigree fabric and traditional customs and beliefs of Gorontalo people and an aesthetic approach, meaning and symbolization in Gorontalo filigree cloth, with the focus of discussion on decorative items on the fabric.

The Karawo motif initially had a very simple form. This is adjusted to the shape of Gorontalo ornament namely:

\section{Line or Geometric Motifs}

Geometric motif ornaments are the oldest type of all decoration elements, which develop gradually from the original (plain) to the artistic geometric, along with advances in science and culture [10].

The geometric motif of the Karawo ornament also includes the oldest motif, considering that it has existed since the emergence of Karawo ornaments in Gorontalo. This motif developed over time along with the development of craftsman skills, availability of textile materials, and the complexity of the demands of the function.

The main motif of this ornament is the rhombus rectangular shape made in various sizes. Medium-sized motifs are placed on large ones with different colors, and then repeated with a constant rhythm six times. Two small motifs between repetitions act as variations to make the shape more decorative. As for the edge motif, the shape of the rhombus rectangle is divided into four and positioned face to face. Among the repetition of groups of motifs, there are small motifs, because the connectors make the pattern look united. All motifs are arranged vertically to create a towering impression. The value of unity feels very strong because of the application of symmetrical balance. 
The square Karawo motif is inspired by the Pahangga. The term Pahangga is derived from the Gorontalo language, which means palm sugar, wrapped in leaves and shaped like two combined pyramids. The shape of the Pahangga is then adapted as a decoration on the aisle pillar for traditional brides in Gorontalo. The designer then adapted the shape of this reward into a Karawo motif.

The shape of the Pahangga, which is an inspiration in creating geometric motifs of Karawo ornaments, has a very noble meaning. The reward was once placed in front of the officials' house to indicate the level of their position the number ranged from five to 13, according to the level. The village head is 5 Pahangga, Marsaoleh or camat is 6 Pahangga, Jogugu or the prime minister is 7-8 reward, Marsaoleh or camat is 6 Pahangga, Jogugu or the prime minister is 7-8 Pahangga, and for the king is 9-13 Pahangga.

This meaning implies the idea that the reward plays a role as a symbol of the rank and authority of a leader in the system of royal government in Gorontalo. The amount of reward refers to the hierarchy of power possessed by a leader, from the lowest position, namely the village head with five reward to the highest position or king with 9-13 reward. The power hierarchy symbolized by the number of rewards is actually a leadership conception for managing government structures so that leaders work in accordance with their authority and the wheels of government run well. Even though the government system changes, the concept remains relevant.

\section{Plant Motif}

Plant motif ornaments include all ornaments adapted from the shape of the plant. The choice of plant type is based on the beauty of the form and symbolic meaning. The beauty of the form includes delicacy, aroma, and benefits for livelihood.

a) Seruni flowers, which have meaning:

- The flowers are beautiful so they represent the beauty of the embroidery craft itself.

- The leaves can be used as medicine (iodine substitute)

b) Breadfruit Leaves (in Bitila Gorontalo), which have the meaning of guarding.

c) Corn Plants

This plant is generally planted by farmers in Gorontalo and is a food source for local people. In addition, corn has become the main agricultural commodity in Gorontalo Province. Corn as an embodiment of the natural environment is represented uniquely and aesthetically in the form of Karawo ornaments.

This shows that Karawo ornaments with plant motifs also play a role as a representation of natural wealth, which is a source of livelihood.

For Gorontalo people, corn plants are a source of livelihood and a symbol of cooperation culture. Corn plants that grow in groups in Gorontalo culture are called Huyula (mutual cooperation), living together harmoniously. Implicitly, corn is valued as a source of livelihood and a symbol of cooperation, because seeds that grow regularly in groups and plantations are carried out jointly by farmers' mutual cooperation. Therefore, the farming community first applied Huyula culture. The Huyula culture is cooperation or reciprocal assistance system among community members for the purpose of society based on social solidarity. The corn motif is a symbol, which represents Huyula culture. In this Huyula culture, there is a value of unity, concern, and equality to achieve community goals. The existence of Karawo ornaments with corn motifs is a medium for communicating messages about these values. This is fundamental because the behavior of the Gorontalo people is indicated to begin to ignore the Huyula tradition that their ancestors have done.

\section{Animal motifs (fauna)}

Karawo ornament with animal motif largely adapted from the shape of a fish. This is considered because of its relationship with the geographical location of Gorontalo Province which is surrounded by the sea, so that various forms of fish are common to local people in their daily lives. Exotic fish shapes have inspired and aroused designers to adapt them to Karawo ornaments. 
Fish species that were adapted as ornaments in images resembling dolphins. The biggest fish motif is described as moving through a circle. The rhythm of fish body movements creates a subtle dynamic impression. The big fish motif is the main motif that is equipped with supporting motifs in the form of small fish and various other motifs, making ornaments look more decorative and complicated. Such harmony strengthens wholeness, through giving the impression of calm and comfort. Karawo ornaments with fish motifs illustrate the dynamics and harmony of the atmosphere of marine life habitat.

Fish species adapted as ornaments in images resembling dolphins and dragons. Where dolphins mean intelligent fish while dragons are a symbol of maritime life.

Over time the motif developed according to conditions such as the symbol of Garuda, the symbol of North Sulawesi (at that time Gorontalo was still in the territory of North Sulawesi Province), coconut trees, Education symbols (Tut Wuri Handayani), office symbols, agencies, flower motifs and so on according with order.

\subsection{Karawo's Artworks Pahangga Geometric Motives}

Geometric motifs of Karawo art have been around since the emergence of Karawo art in Gorontalo and are the most prominent motifs in the pre 1970 period with elements that are still simple and done with the Karawo ikat technique. Geometric motifs then continue to develop in line with the increasing expertise of Karawo art workers in terms of techniques and the development of creative ideas, the availability of increasingly quality raw materials, and the demands of increasingly complex functions so that their shapes become very diverse. Here are among the geometric motifs of Karawo artwork that have undergone development.

Among Karawo artworks, geometric motifs, researchers took one geometric motif as a sample. The selection of motifs as a sample is based on the number of enthusiasts of the motifs and is commonly used for clothing, as evidence that the work meets the tastes of the people of Gorontalo. The arranged motifs are very similar to the shape of the Pahangga (in Gorontalo) which means palm sugar.

The decorative motif (main motif) in the structure of the Karawo motifs of geometric motifs is the rhombus quadrilateral. The motif is made with different sizes (big, medium and small) (Figure 6). The medium size motif is located on a large size motif with different colors (lanes 2 and 3), then repetition with a fixed rhythm six times. The two small size motifs contained among these repetitions are alternating motifs to give the impression of being complicated. The motif on the edge (lane 1), the rhombus quadrilateral is divided into energy and is composed face to face, then repetition six times. On the sidelines of the reptition row of motifs there are small motifs as a link to make it look fused. Other motifs (lane 4) are made the same size and twenty times repetition. All motifs are composed vertically, giving rise to the impression of looming. Unity value feels strong due to the application of formal (symmetrical) balance.

The colors applied consist of three types, namely: golden yellow, purple, and light green. Although the composition of the three types of colors looks contrasting, it still feels unified. This is caused by color repetitions that intersect regularly and interlude the basic color of the fabric on the overall motif. The contrast composition is also felt from the combination of smooth and slippery texture (shiny) on the surface of the fabric with a rough texture on the motif and the field that becomes the background of the motif. The rough texture on the background of the motif is caused by the raw material, namely the bonding of the thread to the fabric that has been perforated.

\subsubsection{Weight or meaning}

The weight or meaning of the Karawo artworks of geometric motifs can be revealed from the source of the idea that comes from Gorontalo traditional artifacts. The geometric motif in the form of a rhombus quadrilateral is processed from the forms of the reward (in Gorontalo language) which means palm sugar which is also often seen on puade pillars (in Gorontalo) which means 
the wedding of a bride. The forms of the reward become the Karawo motif because the meaning contained is very important to convey, related to the kindness of the character of a leader. The good qualities of the leader are the weight or meaning (message) that is to be communicated through motives adapted from the form of the reward.

The purpose of the reward is palm sugar wrapped in leaves that resemble the two forms of pyramid combined. This form of reward is taken as a traditional decoration to convey adati values, so that the reward has meaning. The Karawo craftsmen then adapted and processed the form of the reward that has had that meaning into Karawo motifs, so that the resulting motif also has a weight or meaning (message).

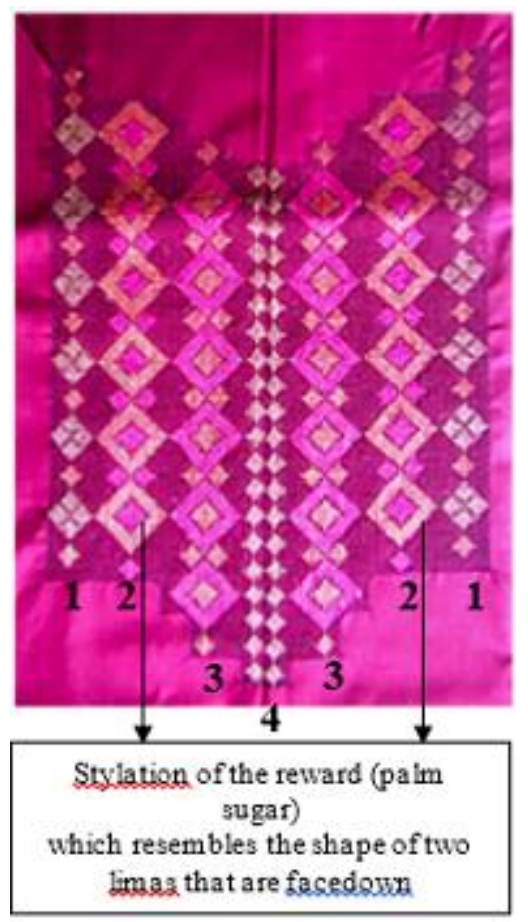

Figure 6. Sample of Karawo geometric motifs

Source of collection of Karawo houses, Sudana 2017

The meaning of Gorontalo traditional reward is a symbol of the dignity or rank of leaders in the government system during the royal period in Gorontalo. The amount of reward refers to the power hierarchy of a leader, starting from the lowest, namely the village head with 3-5 priests, Marsaoleh or camat 6 Pahangga, Jogugu or pamongpraja in the Dutch and royal times, to the highest, namely kings numbering 9-13. The power hierarchy symbolized by the number of rewards is actually a concept in structuring government structures so that leaders work according to their position and authority so that the wheels of government run well.

It can be affirmed that the implied weight or meaning to be communicated through Karawo motifs of geometric motifs is a message relating to the authority or responsibility of a leader in running the wheels of government along with the noble qualities that must be possessed, namely: great, authoritative, courage in taking wisdom or decision, fear of God, sincere work, loyal and dedicated. That custom value is articulated into the form of the Karawo ornament of the geometric motif as weight or meaning.

\subsection{Karawo Plant Motif Artwork}

Plant motif ornaments are all kinds of ornaments arranged from moif or plant elements, both whole and elementary (roots, stems, leaves, flowers, fruits). The choice of plant species to be adapted into ornaments is based on the beauty of the shape or symbolic meaning (Figure 7). 
The beauty of the intended form is not only visual (beautiful views), but also delicacy, fragrance and benefits for life. Plant ornament creation is usually carried out with stylation techniques, which are depictions of something to achieve the beauty of the form by means of the object or object being drawn, which is to enrich each contour on the object or object.

The structure or shape of plant motifs is very varied. Among these works, the samples chosen for analysis were Karawo corn plant motifs.

The work is commonly used and attracted by the community which indicates it is a collective taste, motifs that are arranged more intact (not elementary), and indicate a connection with Gorontalo's natural environment, namely with corn plants. Therefore, the work is considered representative to achieve the research objectives.

The structure of the plant motifs Karawo artwork is composed of several elements or elements, namely: stems, leaves and fruit or flowers. The arrangement of the motives seems to center on one main point of the parent then flows in various directions.

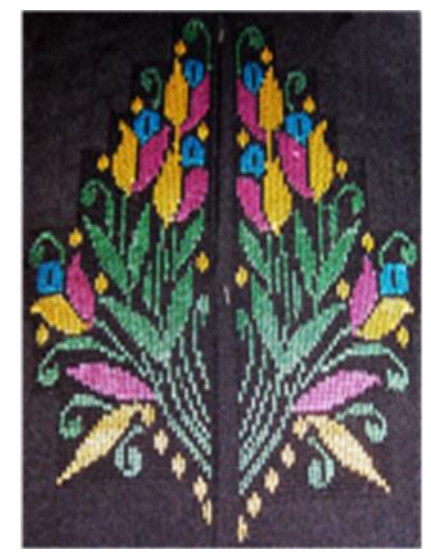

Figure 7. Analysis sample of Karawo plant motifs

Source: Collection of Karawo Houses, Sudana, 2016

The stem motif on the Karawo ornament of plant motifs is made in various directions, slipping under the leaves towards the base of the fruit or sticking out with a circular tip (ukel). The stem motifs, although made with straight lines following the fabric of the fabric, but because they are arranged vary and the rhythm is wavy, then it appears like a line of sticky lines that give rise to gentle dynamics. Variations in leaf motifs attached to the stem are made with different directions (downward, sideways, upward) and different sizes (large and small). The composition of leaf motifs with various variations shows the impression of complexity as natural foliage grows. Meanwhile, the fruit motif is composed clustered on the top and one stalk at the bottom as a counterweight. The fruit motif is the main motif that is highlighted because of its great benefits for human life. The value of unity and integrity arises from the application of a formal (symmetrical) balance. The color that is composed in the Karawo motif of plant consists of four types, namely: yellow, green, blue and purple. The color composition does not include contrast because it has similar properties. The green color of the leaf motif, for example, is obtained from a mixture of yellow and blue so that green has the same properties with blue and yellow. Even though the compositions are not in contrast, because the intensity of each color is strong (bright), it produces dynamics that tend to be strong and dynamic. The composition of the motifs and the composition of colors in the artwork of the plant's Karawo motif gives rise to a fresh and vibrant atmosphere.

\subsubsection{Weight or meaning}


The emergence of Karawo art with motifs adapted from corn plants related to Gorontalo natural resources (mainland), which are mostly mountainous and dominated by corn plantations. Ornaments of Karawo plant motifs that are processed from the shape of corn plants are actually representations of Gorontalo's natural wealth which is the source of people's lives. In this context ornaments become a marker of human attachment to their environment.

Corn plants are not included in plants used in Gorontalo customs, but are plants that are a source of community livelihood and become a symbol of mutual culture in the life of Gorontalo people. The value of the usefulness of corn plants as a source of life, both for humans and animals is one of the drivers of the birth of corn motif Karawo art. This value is also the weight or meaning (content) contained in the corn motif motif Karawo artwork. From the use of the types and compositions of symbolic traditional colors (purple-majesty, yellow-wise, green-responsibility), the motive seems to remind the community to appreciate the usefulness of natural potential as a source of life to be used wisely and responsibly so that its existence remains sustainable.

It can be said, that the weight contained in the Karawo artwork of timbuhan which is adapted from corn plants is a message that reminds humans of the wealth of natural resources to be used wisely for the survival of life, and a message about the values of Huyula (mutual cooperation) that patutu is preserved, because the behavior of the people of Gorontalo is indicated to begin to ignore the Huyula cultural traditions that have been carried out by their ancestors.

\subsection{Karawo Art Works Animal Motives}

Animal motif ornaments are a type of ornament that is adapted from fauna or animal forms, whole or elementary (head, body, legs, etc.) and often combined with other motifs. The choice of the type of animal created into an ornament is based on: symbolic value, beauty of form, character (character), likes, benefits for life, or a combination thereof.

These reasons triggered the emergence of varied motifs of animal motifs that were in great demand.

Among the animal motifs of Karawo artworks, one was chosen as an analysis sample, namely Karawo artwork of fish animals (Figure 8). The work is considered to meet the collective aesthetic tastes of the people of Gorontalo which are indicated by the number of produced and sought after consumers. The motives arranged in the work seem more varied than other works. Fish, which are the subject of their material, are closely related to Gorontalo's natural environment and are a source of livelihood for Gorontalo people.

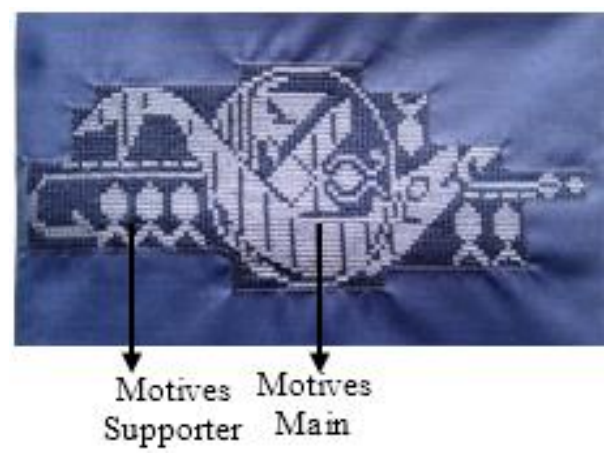

Figure 8. Analysis sample of animal motif Karawo artwork

Source: Photo: personal, 2019

The type of animal created to be the motif or element in the Karawo artwork of the animal's motif is fish. Fish species adapted as ornaments in images resembling dolphins and dragons. Where dolphins mean intelligent fish while dragons are a symbol of maritime life. The biggest fish motif is described as moving through a circle, and around it are several small fish. The small fish are made in a simple shape. Among the fish motifs are other varied motives, so the pattern of the structure appears more decorative and complicated. Two parallel lines (horizontal) in the middle of the pattern image the boundary between the sea and the sky when viewed from the beach. The 
big fish motif positioned between (above and carried) the horizontal line illustrates, that the fish is moving (jumping). The rhythm of the fish's body movements creates a gentle dynamic impression. The structure or pattern of the Karawo artwork of the fish motif is composed with asymmetric balance so that it seems more dynamic. The value of unity or wholeness is felt by the appearance of large fish motifs between motifs of small fish and other motifs, which become accentuation or center of attention.

\subsubsection{Weight or meaning}

The Gorontalo people do not see the fish motifs of Karawo art as only representations of certain fish but from all fish habitats. The weight of the fish motif can be revealed from the beginning the emergence of an idea to adapt the shape of the fish into a Karawo motif.

The idea of the emergence of fish motifs has no bearing on the customs of the people of Gorontalo, but because of Gorontalo's natural (sea or lake) suggestion which is rich in various types of fish. The inspired designer to process fish forms became the motif of Karawo ornaments, because he felt fish was important as a source of livelihood and food for the community. From there it can be interpreted, the weight contained and wanted to be conveyed by the designer through the fish motifs, is an idea in the form of a message to remind the public of the importance of fish as a source of life obtained from territorial waters. Fish habitat is not associated with Gorontalo customs, either as a suggestion for ceremonies or certain traditional symbols, but fish is considered a source of food and livelihood, so fish are widely adapted as decorative ornaments for Karawo art. But that does not mean the motives are not weighty or just an expression of beauty that is beautiful to look at. But the fish motifs are loaded with weight in the form of messages to awaken (remind) the community about the preservation of natural environment habitat (sea, river, lake) as a source of livelihood.

The weight or meaning contained and wanted to be conveyed through Karawo artworks of fish motifs is not an overflow of feelings (emotions) or certain traditional symbolic meanings. The weight of fish motif Karawo art is an idea that is intended to be conveyed to the public with the aim of realizing and convincing the public about a problem related to environmental preservation and advice to support government programs in the development of the fisheries and marine sector.

\section{CONCLUSIONS AND SUGGESTIONS}

\subsection{Conclusions}

Based on the description of the data collected from the results of the research in the field, some conclusions can be drawn, namely:

1. The influence of culture from the Philippines is known to have a strong influence on the emergence of Gorontalo filigree namely manila filigree.

2. Gorontalo Filigree has many distinctive motifs but based on various considerations the author only chooses 3 works of the Gorontalo filigree motif to be examined carefully to gain knowledge of the motive characteristics and aesthetic values. The name of the motif is the geometric motif of the reward, the motif of the millu (corn) and the motif of the animal. From the results of the study, it can be seen that Gorontalo filigree has an aesthetic value consisting of unity formed from the overall decorative motifs displayed, complexity formed from complexity in the manufacturing process, and intensity, namely seriousness in the manufacturing process or impressions displayed on filigree motifs. Of all these distinctive motifs show a relationship between humans and humans and humans with nature.

3. Gorontalo filigree has a distinctive color characteristic such as purple, golden yellow (gold), silver and dark green, and displays decorative motifs related to flora and fauna. Nearly all of the typical motifs of Gorontalo filigree have supporting motifs in the form of dots and lines that form a distinctive ornament. 
4. Gorontalo Filigree implied geometric motifs of messages that are intended to be communicated relating to the authority or responsibility (position) of a leader in carrying out the wheels of government along with their noble qualities. Kerawang Gorontalo plant motifs especially in corn plant motifs imply a message that humans are mutually tolerant, respect each other, and help each other (mutual cooperation) between all groups of society. Kerawang Gorontalo has the meaning that humans must synergize between nature and humans through tolerance with each other and love between people and different human statuses.

\subsection{Suggestions}

Based on the results of the research conducted, in developing Gorontalo filigree in particular the Gorontalo filigree motif needs to be done some of them:

1. Providing contributions in the form of knowledge to the wider community about the aesthetic value of Gorontalo filigree.

2. Provide knowledge of the meaning and value of Gorontalo filigree aesthetics to students as the next generation of Gorontalo culture and society in general.

3. Providing information to the Karawang industry center about the aesthetic value and knowledge of filigree artwork from Gorontalo.

4. Providing information about the aesthetic meaning and value of Gorontalo filigree to the Tourism Office for the sake of conservation and development.

\section{ACKNOWLEDGMENT}

Praise be to Allah SWT, because with His mercy and grace the author can compile this research entitled " STUDY OF DECORATIVE VARIETY IN GORONTALO KARAWO FABRIC IN AESTHETIC AND SYMBOLIC ELEMENTS ".

\section{REFERENCES}

[1] S. Hassan, Ensiklopedi Indonesia, jilid 3. Jakarta: Ichtiar baru-van Hoeve. 1982.

[2] Denzin, Lincoln, Handbook of Qualitative Research. Yogyakarta: Pustaka Pelajar. 2009.

[3] Hasdiana, Fendi Adiatmono, dan Ulin Naini. Peningkatan Brang Image Kerawang Melalui Penciptaan Desain Ragam Hias Kreatif Beridentitas Kultural Budaya Gorontalo Untuk Mendukung Industri Kreatif. Laporan Hasil Penelitian. Lembaga Penelitian Universitas Gorontalo. 2013.

[4] Niode, Alim S. Gorontalo: Perubahan Nilai-Nilai Budaya dan Pranata Sosial. Jakarta: PT Pustaka Indonesia Press. 2017.

[5] Daulima, Farha, Busana Adat Gorontalo. Gorontalo: Dinas Pariwisata. 1999.

[6] Djelantik, A.A.M, Estetika sebuah Pengantar. Bandung: Masyarakat Seni Pertunjukan Indonesia. 1999.

[7] Guntur, Motif Hias Alas-Alasan dalam Ritual Tingalan Jumenengan dan Perkawinan di Keraton Kesunanan Surakarta: Kajian Bentuk, Fungsi dan Makna . Tesis. Program Studi Pengkajian Seni Pertunjukan dan Seni Rupa Universitas Gadjah Mada. 2010.

[8] Dharsono, Estetika Nusantara. Surakarta: ISI Press. 2012.

[9] Sudana, I Wayan, Konsep Pengembangan Seni Karawo Gorontalo. Disertasi. Pascasarjana, Universitas Seni Indonesia Surakarta. 2018.

[10] Matey, Meyer Worang, Kajian Motif, Fungsi dan Makna Kerajinan Kerawang Moronge di Kabupaten Kepulauan Talaud. Tesis. Penciptaan dan Pengkajian Seni, Institut Seni Indonesia, Surakarta. 2011. 